Britain; but the proof of their marine origin remains to be written. They contain no undisputed organic remains. The rocks in which they are intercala' ed are not proved to be altered sedimentaries. There were numerous animals living in the Salopian area in the Longmyndian epoch, for their trails are quite abundant in some of the slaty seams; but, if there were no carbonate of lime in the sea, there could, of course, be little material to provide shells for its inhibitants. Numerous creatures of many types might have been evolved, whose soft tissue would leave no traces in the rocks. In succeeding ages, as the forces of denudation cleared off the newer Archæan, and cut down into partially decomposed crystallines, abundance of calcic carbonate would be carried down into the sea.

Wellington, Shropshire, March I.

C. Callaway.

The Artificial Spectrum Top.

IN your issue of March 7, we notice a letter from Dr. Dawson Turner, in which he says he has had a "Benham's Spectrum Top" made on glass, by an optician, for the lantern, and recommending others to do the same.

Will you allow us to state that we have sold all rights in this copyright top to Messrs. Pears, reserving to ourselves only the sole right of making them as lantern slides, in which form we have been supplying them for some time.

The tops can be obtained from Messrs. Pears, and the lantern slides from us ; any one else supplying either will, of course, be infringing the copyright. NEWTON AND CO.

\section{RESEARCH IN EDUCATION.'}

$\mathrm{N}^{\mathrm{O}}$ branch of research work at the present day offers greater opportunities, whilst none is more urgently in need of original workers, than that which lies open to the teacher in school or college ; and it is surprising how small an amount of sound work is accomplished in it-how little it is realised that there is a science of education to be developed by persistent study, application and research. An analytical habit of mind seems to be the very last qualification sought for in a teachersuch is the influence acquired by clerical instructors in the course of centuries by the universal extension of methods of teaching originated in the monkish cell and cloisters, and wielded with but slightly diminished force, even to-day, by their lineal descendants, whose voices still preponderate in educational affairs. Conservative and sheep-like-as we cannot fail to be if all our early life be spent in an atmosphere of dogmatism - the slowness with which we evolve and apply new ideas is phenomenal. It cannot be that sterility is the outcome of excessive labour in days gone by, and consequent exhaustion of the soil; still less, that it is owing to absence of demand; for it is only too clear that the entire change in the conditions of life witnessed within the century renders it necessary that our children should be so educated that they may successfully grapple with the new conditions, and it stands to reason that the preparation which sufficed in the case of their forefathers must be insufficient in theirs. This is now being universally recognised, but all too slowly and imperfectly. Thus the academic oration first on my list, delivered only in September last, at Freiburg, by the Professor of Anatomy, is a vigorous protest against the practice 3 "Ueber die Vorbildung unserer akademischen Jugend an den humanistischen Gymnasien."-Programm wodurch zur Feier des Geburtsfestes seiner königlichen Hoheit unseres durchlauchtigsten Grossherzogs Friedrich im Namen des academischen Senats die angehörigen der Albert-Ludwigs Universität einladet der gegenwärtige Prorector Dr. Robert Wiedersheim. (Freiburg, r894.)

"The Teacher's Manual of Lessons on Elementary Science." By $\mathbf{H}$. Son.)

"Practical Lessons in Physical Measurement." By Alfred Earl, M.A., "“nior Science Master at Tonbridge School. (Macmillan and Co.)

"A Laboratory Manual of Physics and Applied Electricity." Arranged and edited by Edward L. Nichols, Professor of Physics in Cornell University. Vol I. Junior Course in General Physics, by Ernest Merritt and Frederick J. Rogers. Vol. II. Senicr Courses and Outlines of Advanced Work, by G. I. Moler, F. Bedall, H. J. Hotckiss, C. P. Matthews, and the Editor. (New York and London: Macmillan and Co.) No. I 324 , vor.. 5 I] prevailing in the German "Humanistic" Gymnasia of devoting an enormous proportion of the school-time to classical studies, and the consequent neglect of drawing, natural science, geography and modern languages, as well as of gymnastic exercises, which is very strange, as he points out, when it is remembered that the meaning of gymnasium is a place for athletic pursuits. He especially complains of the way in which exercises in classical style are insisted on and monopolise attention, and strenuously advocates their banishment from the three lowest classes at least. He refers with feeling to the pressure which is brought to bear in school and at home on the child to whom such work does not appeal, and the unhappy state of house and family on "style-days," remarking that every one who, like himself, has had this experience in his own person and that of his children, will sympathise with this view. He tells us that his own bitter experience of thirty-five years ago still follows him in his dreams, and that he can never forget the encouraging words hurled at him by the master of the "Prima" of the Stuttgart Gymnasium when he had done a bad Latin exercise"You never in your life will come to any good, as sure as my name is Schmid." Is not this too often the attitude of our schoolmasters, and is it not too often forgotten that the human mind, fortunately, will not in all cases respond to one uniform system of treatment? Surely the time must soon come when it will be the main duty of headmaster and headmistress to study their scholars, and assort them in accordance with their aptitudes; when no headmaster will set down a boy as of inferior intellect merely because he does not get on well on the classical side, and cannot therefore be made use of with effect as the winner of a scholarship at the university - a course which some of our most noted beadmasters appear too often to countenance if report belie them not. Fortunately we are not here so much the victims of educational overpressure as is Germany under the terrible influence of its military system, although there is enough to complain of, especially in the case of girls' schools, owing to the improperly large number of subjects included in the time-table; moreover, examinations, such as the London University Matriculation, are exercising a most insidious effect: and now that County Councils all over the country are granting scholarships on the results of examinations, it behoves us to be much on our guard, and to take steps to secure that all such examinations are so conducted that reasonably welltaught and reasonably intelligent scholars can be submitted to them without any interference with the normal school course. Prof. Wiedersheim, referring to the very one-sided training given in the Gymnasia to the future jurist, theologian and philologist, calls attention to the importance to such students of some knowledge of natural science in the following passage, which undoubtedly deserves our attention, as we suffer in like manner: "Kein Gebildeter vermag sich heutzutage dem Einflusse, welchen die Naturwissenschaften auf das Geistesleben aller Culturnationen gewonnen haben, mehr zu entziehen. Die ganze moderne Weltansschauung, unser Leben und Denken, die Forschung auf allen Gebieten-ich erinnere nur an das auch in der vergleichenden Linguistik zur Geltung kommende genetische und causale Element-stehen unter der Signatur der inductiven Forschung. Mit diesem Umschwung hat auch das humanistische Gymnasium zu rechnen, sollen nicht Juristen, Philologen und Theologen in ihrem ganzen Bildungsgang einen Fehler aufweisen, der oft nicht mehr gut $z u$ machen ist." But this is nowhere properly recognised. And yet Charles Kingsley long ago dreamt of a day when every candidate for ordina. tion should be required to have passed creditably in at least one branck of physical science-if only to teach him the method of sound scientific thought. Dr. Percival 
has urged in Convocation at Oxford that the elements of natural science should take their place in Responsions-side by side with the elements of mathematics, and equally obligatory. The late Master of Balliol, I believe, also recognised the importance of such a change ; but the reformer who will carry it into effect is not yet in evidence, and perhaps his services will not be required, as the schools must soon do that which the universities ought long ere this to have had the foresight to enforce. We are, in fact, only beginning to escape from the bonds of tradition, and it cannot be denied that our release is being gradually effected-not through any action taken by our ancient universities, but rather in spite of them-mainly through the persistent efforts of a small but untiring and resolute body of outsiders whose position has yet to be made clear to the public, most of whom undoubtedly regard the teaching of experimental science much in the way that the introduction of pianos into Board Schools was regarded a few years ago by a majority of Londoners-as something very nice for those who can afford it, but as in no sense a necessary element in the education of the masses. We, on the contrary, contend that the human mind cannot, as a rule, be completely educated by exclusive attention to literary and $m$ ithematical studies, and that lessons in experimental science must form an integral portion of the entire school course, because such lessons alone afford the means of fully developing a side of the intelligence which perhaps more than any other is of importance in life - the faculty of observing and of reasoning correctly from observation: with Kingsley, we desire that the method of sound scientific thought should be taught universally in schools, to the exclusion of dogmatism and eyelessness ; and we desire to inculcate habits of selfhelpfulness and handiness. The motto from Montaigne adopted by Prof. Wiedersheim fully expresses the modern view of education: "Es ist nicht ein Geist und nicht ein Körper den wir erziehen sollen, sondern ein Mensch, und wir dürfen ihn nicht theilen." Hitherto more often than not, we have cut him up into pieces, and thrown the most important aside. It is only in Germany that a public address on such a theme can be delivered in celebration of the birthday of a Royal Highness-here we must fall back on the British Association; but this body has strangely wasted the unrivalled opportunities which its organisation affords of appealing to the public on such matters.

Fortunately, help seems to be at hand from a quarter from which it was least expected, as the schoolmasters are at last awakening to the necessity of reform, and have themselves taken action which, if persevered in, must be attended with most important consequences. At the recent meeting of the "Incorporated Association of Head Masters," which now numbers nearly 300 members, on the motion of Mr. C. Stuart, of St. Dunstan's College, Catford, London, S.E., it was resolved-

(a) "That the Association is of opinion that Examining Bodies should encourage a more rational method of teaching science, by framing the syllabuses in such a manner that the practical work required may be strictly illustrative of the theoretical instruction given."

(b) "That it be referred to the General Committee to appoint a small Sub-Committee, so that a report may be presented to the next summer general meeting containing detailed suggestions, which it is proposed to make to Examining Bodies concerning examinations in science."

As I ventured to point out, when speaking on these resolutions, the consequences of their adoption will probably be far greater than those who have accepted them are likely to have contemplated. Thoughtful examiners have long been waiting for a sign : no one has been more dissatisfied with their examinations than they themselves have been, but it has been impossible for them to examine much in advance of the teaching, as it would obviously have been most unfair to candidates to make them victims of a system for which they are in no way answerable; and at most it has been possible to gradually give a practical turn to questions in subjects which can only be taught properly by means of practical lessons. The gage thrown down by the headmasters will, therefore, certainly be uplifted forthwith by all examining bodies whose work is not done in a purely perfunctory spirit, and the schools will find that of their own accord and most properly they have brought about a complete revolution in their own methods of teaching; for if they ask for proper examinations, they necessarily must be anxious to see corresponding proper methods of teaching adopted in their schools, and will provide for their introduction. Nothing could be more gratifying to those among us, who, during years past, have been pointing out the necessity of introducing radical changes and improvements.

A serious responsibility will now be cast on teachers, and it is clear that if workers are forthcoming with minds imbued with the proper spirit of inquiry, there will be ample opportunity of gaining distinction in the field of educational research. There is clearly much leeway to be made up, for although we are all agreed that every branch of natural science must be taught practically, we are, unfortunately, far from always practising what we preach-the system of mere lesson learning not only prevails far too widely and extensively, but is far too frequently regarded with approval as all-sufficient. The practical and theoretical work are seldom, if ever, made sufficiently interdependent-in fact, this is the blot on which the headmasters have laid their finger. Even in my own subject, chemistry, which is generally sup posed to be in a stronger position than most others, as it has been taught practically from a considerably earlier date, much misconception prevails, and we are credited with having advanced far more than we deserve. Liebig, the founder of the laboratory method of teaching, appears to have taught chemistry - we are told that when Hofmann became a student under him, although a beginner, he was set to work at research; and we know that Liebig gave all his students problems to solve. But the march of progress and, especially, the press of numbers have long since led to the introduction of the anti-research method which some of us irreverently term test-tubing. Such and such is the case-do so and so, and if you do so and so, this and that will happen, are instructions so often dinned into beginners' ears, that they become part of their very being, and they in consequence are ever afterwards unable to give a straightforward account of what they have done, and insist, instead, on telling you, the teacher, what to do and what will, not what does, happen. Nothing is more rare in a chemistry examination paper than a straightforward answer, not in terms of if and will, showing that the writer is describing from personal knowledge something that has been done. The true object of experimenting is thus lost sight of as the habit grows of requiring to know in advance what will be the outcome of any particular experiment : the spirit of curiosity is rarely awakened. At the same time the worst possible literary style is encouraged, a real opportunity of developing a good one being most perversely sacrificed. Analytical tables were originally introduced with the laudable object of presenting knowledge to the student in a systematic form, but gradually we have allowed them to pass from the position of good servants to that of bad master-mainly because they offer so very convenient a method of keeping students occupied with a minimum of attention and labour on the part of the teacher and at a minimum cost, as a few test-tubes and weak solutions form almost the only stock in trade. Quantitative work is also done in an almost equally per-

No. 1324 , vOI, $5 \mathrm{I}]$ 
functory way, as a rule, with the object of qualifying the student to do technical analyses, and the importance of measurements in establishing first principles is never taught practically, but is merely talked about: the result is that only the few who study the subject professionally, really grasp the meaning of the fundamental quantitative conceptions of our science. It is not surprising that under such a system, being helped over every stile, and having no training in research methods, our students are so very rarely properly educated. And altogether false ideas have arisen also as regards the value of true research work, this having been allowed in far too many cases to degenerate into mere preparation-making, or mere measurement work. There are many among us who have recognised these shortcomings in our method, but tradition exerts its all-powerful influence, and little short of a revolution is required to reintroduce a truly scientific procedure into our schools and examinations-to lead teachers to recognise that the only proper method is to make students researchers from the very outset. These remarks are but prompted by the desire to acknowledge that if I throw stones, I am fully aware that I dwell in a glass house ; and especially to make it clear what is the point of view from which I regard the problem before the teacher of any branch of natural science.

The teaching of physics practically is of quite recent introduction. When I was a student at the Royal School of Mines, there were only lectures on physics; and when, about fourteen years ago, my colleague Prof. Ayrton and I visited all the chief continental schools, we found the practical courses in a very embryonic state. Now, although we have nowhere a laboratory which will compare in size or completeness of fittings with the palace erected at Zürich, practical physics is taught in all science schools and colleges, and the London University requires even candidates at the Intermediate Science and Preliminary Scientific (M.B.) examinations to pass a practical test. Many of the courses are very complete. I shall not easily forget the pleasure which I experienced on the occasion of a recent visit to Prof Quincke's laboratory at Heidelberg from seeing there the marvellously simple, but yet exact, apparatus used in the practical course ; the insight into the inner meanings of things afforded by his arrangements struck me as most perfect, and led me to wish that it were possible to teach my own subject so as to give the course an equally high educational value. There are also nowadays many admirable books from which the student may gather instructions how to make experiments in the various branches of physics-there can be no doubt, in fact, that the practical text-books in this subject are generally of a very high quality. But $I$ venture to think that they need modification in some not unimportant particulars. Whilst in advance of the practical books at the disposal of the chemist, inasmuch as they stand in direct relation to the instruction in theory, being intended, as a rule, as Prof. Nichols happily states in the introduction to his first volume-to illustrate and therefore impress more thoroughly on the mind the principles and laws which have previously been taught by text-books or lectures, yet for this very reason the attitude in which they place the student is a wrong one. A "law" is dogmatically stated, and the student is told how to verify it experimentally, so that the young worker, instead of being led to inquire, is perpetually told in advance what are the facts, and is instructed to repeat the experiments merely in order to prove certain things. Consequently, in physics as in chemistry, students are far too little encouraged to find out things and to help themselves-instead of becoming imbued from the outset with the spirit of inquiry, they are led to expect and require assistance at every step. While galvanometer needles wag, they calmly put their hands into their pockets, and it becomes very difficult to induce them ever to adopt any other mental attitude. Whilst therefore our teaching is enormously improved by bringing students into personal contact with the facts to an extent altogether undreamt of even in my student days, by the very wealth of appliances now at their disposal, they are fast becoming spoilt-perfect sybarites, and the self-helpfulness engendered by the rude and scanty apparatus of days gone by is strangely infrequent. The system apparently fails to engender or develop originality and powers of observation, however much it may tend to train even well-informed and exact workers; but I imagine that little more than a change in the form of the instruction is required, in order to make it impossible to say of any one, "that he knows about all sorts of things, but he can't do them," the only text, it seems to me, worth preaching from at present. The principle it embodies is the one of all others upon which the whole practice of education must be built up, whatever the subjects taught ; but it is undoubtedly one which has not been kept persistently under notice, as it should have been by teachers generally.

The habit of mind complained of, so characteristic of all but a few gifted individuals among our students, is probably largely engendered by the training they have received during the early years at school ; and it is incumbent on all teachers working in the field of educational research to do their utmost to develop methods which will counteract the evil effects of mere lesson learning and desk work, as these cannot be altogether dispensed with.

As illustrating-how not to teach elementary science, the "Manual " first on my list must be assigned to a high place; no doubt the intention is good, the information may be interesting and useful in its way, although often very bald if not inaccurate, but such a book has no right to figure as a "Manual of elementary science." It comprises instructions for object lessons, on every possible topic, to children in the six standards of elementary schools, in the form of very short chapters either of "special information for the teacher" or "introductory specimen lessons," and of "notes of lessons" in which, in parallel columns, the kind of question to be asked is set out under "method," and the information to be imparted under "matter." As in all books of this class, far too much is attempted. In the hands of a really capable teacher-who would not need such a book, however,object lessons may be made of the highest value, but even in such hands the tendency always is mainly to impart information; the kind of lessons that would be given by the uninstructed teacher gaining inspiration from Mr. Major's manual, is easier imagined than described, and their educational effect could not fail to be harmful. We are better without such "science," and had better stick to the plain bread and butter fare of "prescientific" days, if we cannot teach in such a way as to inculcate the practice of scientific method; in fact, we do not want "science" teaching of any kind introduced into elementary or, indeed, any schools unless it take the form of work done by the children themselves: in no other way can the end we have in view-that of training them to do, not merely to know-be achieved, and any other kind of teaching must be a pretence and but an encouragement of priggishness.

As regards the course of the future, there is no doubt that much may be done in very early days to lead children to take note of everything about them, to describe what they see, and to collect and describe common materials of every kind. Some slight preparation for the study of botany may also be laid at this stage. But the science lessons proper begin when the children know enough arithmetic to measure and weigh. All who have studied the problem practically are probably agreed that simple measurement lessons must form the foundation, and there cannot be a doubt that it is both No. 1324 , vor. 51$]$ 
desirable and possible to largely incorporate these with the arithmetic lessons - to teach parts of arithmetic and some geometry practically, in fact. Gordon's "Elementary Course of Physical Science" is probably the type of book which will be used with advantage at this stage, judging from the success the course has met with in Board Schools commencing with the fourth standard.

But the pioneer worker in this field is Prof. Worthington. His admirable little book," An Elementary Course of Practical Physics," published in $188 \mathrm{r}$, well known to all teachers of physics in schools, was expanded in $\mathrm{r} 886$ into a larger work, "A First Course of Physical Laboratory Practice." These books have been of the very greatest service, and have probably rescued physics from being made a cram subject in schools; but they are scarcely simple or comprehensive enough for such young workers as I am contemplating. As they are intended to be used in connection with lectures, the motive for each experiment is rarely explained at sufficient length, and unfortunately they have the fault common to all such books, to which $I$ have referred above, that the student rarely approaches the experiment in the attitude of the would-be discoverer.

Mr. Earl's book, although it deals only with measurements of length, mass, and time, is of greater length than Prof. Worthington's, but it does not need lectures to supplement it. It has a short but admirable preface, showing that the author has grasped the nature of the problem to be solved, but it is one thing to do this and another to succeed in solving it; and here $I$ think he has been less successful. The style is far too didactic-the descriptions are far too elaborate - the aim is too high, and far too much is told, not enough left to be found out: to use a homely phrase, which I trust will not be misunderstood, far too much fuss is made about the work. Such work should be done by young children; it must not be postponed until the evil effects of desk work have warped the scholar's mind, and natural curiosity begins to die out. But the book is far above such students. What, for instance, is the value of an introduction telling us what science is, and why we learn it? If taught to work, children will very soon insensibly learn to appreciate what they are doing, and nothing is gained by pointing out to them, for example, that "each individual stands a centre for himself of all things, knowing that around him are centres of endless variety, \&c." Platitudes such as these are out of place in an elementary text-book, and they are beyond children of nine to twelve years of age, by whom simple measurement work will ere long be done in schools generally. In the next chapter, in like manner, we find at the outset a somewhat elaborate disquisition on the meaning of the words standard and quantity, and a description of how measurements of length are made, and then follow directions for a series of exercises : children cannot grasp such disquisitions, and are wearied by them, but most of them will use a foot or centimetre rule with great pleasure. This criticism may be applied to the book generally - the introductory instructions are too frequently high-flown, and too many refinements are introduced into them and into the exercises. The book, in fact, contains material enough both for a junior and a senior course, and would be more generally available if the matter were thus rearranged. But whilst objecting to it on the score of over-elaboration and absence of that simplicity of statement which is indispensable in a book to be used by young beginners, taken as a whole, and regarded from what I conceive to be the author's point of view, it is a contribution to educational literature of great value. The short preface alone is a manifesto of singular importance, coming as it does from a teacher in a public school of high standing. We find in it the remarkable and, I believe, novel expression-the "scien. tific sides" of Public Schools, one, it may be hoped, that will soon take the place of "modern side," to which so great a stigma is attached through the ill-advised action of masters having sympathy only with classical training-action which has led to the modern side being often characterised as the refuge for the intellectually destitute; if the modern side once become the seat of training in scientific method, a fair share of the intellect of the school being allowed to it, there cannot be a doubt that it will soon reap payment "by results" sufficient to secure to it an honourable revenge. To return to the preface, we read that care has been taken to make the course logically progressive, the end in view being to train boys to observe accurately, to reason rightly, and to front nature with an open and inquiring mind. That it must be admitted more generally than is customary that the retention of facts should be subordinate in scientific education to a sound comprehension of them, a mind which has been trained to observe and compare accurately being more likely to acquit itself well in the world. That the right way of learning is chiefly to be cultivated, the matter being obviously less important than the method in learning science, and a logical and inquiring habit of mind being more valuable than the memory of facts and laws, as it is better equipment for future research and knowledge. It is urged that the course should afford some training in correctness of expression and accuracy of language, no insignificant part of scientific education, although this is seldom recognised. Lastly reference is made to the lack of continuity in work often prominent as a defect, especially in the modern sides of schools, and to the fact that much of the average "capacity of learning" is never utilised, owing to frequent change both of subject and matter. The book may serve in some degree, the author suggests, to bridge over with safety the distance between the laboratory and other classrooms, by acting as a Practical Arithmetic and, to some extent, as a Practical Grammar. Trite as some of these remarks may appear to be, those who are aware of the state of affairs in schools will know that, tested by the standards which generally prevail, they are the rankest heresy, but none the less heresy that must ere long revolutionise existing beliefs and practices. In fine, I am inclined to regard Mr. Earl's book as the account of an important research some results of which he has described in a previous publication, this being his second appearance as the author of an educational work. There is the clearest evidence that he has set himself to work out a problem of which he was able to realise, perhaps, only the general nature at the outset; and that, as so often happens in experimental inquiries as experience is gained, the nature of the underlying problem has been more clearly grasped as the work progressed, and important modifications of procedure have consequently been introduced. I look forward with expectancy to his next memoir, in which the results of his further studies will be presented to us, I trust, in far less elaborate guise, so as to render them available to the simplest understandings.

"The Laboratory Manual of Physics and Applied Electricity," arranged and edited by Prof. Nichols, of Cornell University, U.S.A., is intended as a college course, and is stated to be the outgrowth of a system of junior instruction which has been gradually developed during a quarter of a century, and I shall therefore venture to criticise it broadly from an outsider's point of view, as though it were a report on the results of an inquiry, with reference to its general character and the arrangement of the subject-matter. The first volume by Messrs. Merritt and Rogers is intended for beginners, and, we are told, affords explicit directions together with demonstrations

NO. I 324 , vOL. 5 I $\rceil$ 
and occasional elementary statements of principles. It is assumed that the student possesses some knowledge of analytical geometry and of the calculus; also that he has completed a text-book and lecture course in the principles of physics. Here we may at once join issue with the authors. If, as is so frequently and indeed almost always the case at present, the student come to college knowing a good deal of mathematics and no physics, the first assumption is a legitimate one, but it is time that we began to insist that such educational abortions should not be reared, and that girls and boys be no longer allowed to grow up so ignorant that, although they have learnt a good deal of mathematics, they require to be told, when they come to college, how to use squared paper, how to make simple experiments illustrating the principle of the parallelogram of forces, how to roughly determine density by weighing in water and by means of a bottle-all of which, as well as a number of other practical arithmetic exercises for children, are included by Prof. Nichols in his first volume. The incongruity is made still greater by the appearance in the introduction, ten pages after the description of the graphical method of representing results, of a somewhat elaborate discussion of "probable error" and the application of the method of least squares. Surely, also, no student nowadays should be allowed to complete a text-book and lecture course before entering on practical work-are we not seeking rather to invert this order? Were it not that the editor tells us that it is not expected that the experiments will be taken consecutively, the book might be regarded as helping teachers in the choice of a properly graduated course of experiments ; and with this confession before one, it is impossible also to take exception to the somewhat extraordinary classification of the experiments - an instance of which is afforded by placing an exercise on the measurement of the curvature of a lens by means of the spherometer first in the course, at p. 26 , whilst the determination of relative density " roughly" by weighing in water is relegated to chapter ii. p. 8o. Some indication of the editor's experience as to the order in which the experiments are advantageously arranged in a junior course would have been valuable, as even to meet the exigencies created by the simultaneous presence of a large body of students, it is scarcely desirable to take physical exercises in any order. Again, we are told that no attempt has been made to provide a complete and sufficient source of information for laboratory students-on the contrary, it has been thought wise to encourage continual reference to other works and to original sources, so that it is impossible to complain of the book on the score of the incompleteness of many of its descriptions.

The second volume is more interesting, logical and original, and less fragmentary. It is intended for students who have completed the "course" in vol. $i$. and who are prepared to take up special work; in it the needs of those who are in training to become electrical engineers have been specially considered-a sign of the times-and it is for them especially that the parts treating of applied electricity, beat, and photometry have been written. Parts i. and ii. occupy about half the book, and comprise 53 direct and 64 alternate current experiments, the intention clearly being to frame a systematic course suited to those who have gone through a simple qualifying course in general physics. The instructions are very tersely worded, and but serve to give general guidance - which is very desirable in the case of students in whom it is desired to develop habits of independence. Immediately after the electrical engineering course, there is a very short section on electric-light photometry. Following this comes the least satisfactory section in the book, that on beat-dealing with the experimental determination of specific heats, heat of combus- tion, vapour pressure, vapour density, heat of vapourisation, mechanical equivalent of heat, cubic expansion, and measurement of temperature by means of thermoelectric couples. Much of this might with advantage be placed in the qualifying introductory course, and the engineering student would gain little from the exercises which do not properly find a place there. Moreover, this section is grievously behind the times in many respects - undervapour density, not only is the sole method described "the classic one used by Dumas," but the picture is that which has figured in every text-book since Dumas' description was published in 1826 , showing a stove which it would be impossible to find. Experiment 9 is headed, "Use of the Favre and Silbermann water calorimeter," an instrument which it is difficult to imagine in use by students. But Mr. Matthews, who is responsible for this section, is clearly not a Rip van Winkle, as he also describes the Bunsen ice calorimeter and Berthelot's heat of vapourisation apparatus.

Part. iv. of the second volume comprises outlines of advanced work in general physics, based chiefly on researches done in the physical laboratories of Cornell University, written for the use of students who have completed the routine work, and desire to enter upon original investigation. This section will scarcely be of value to outsiders, as every competent head of a laboratory has problems enough awaiting solution, and a textbook of research is scarcely a much-felt want. Excellent advice is given at the outset of this section, and yet it is, in part, of such a kind as to bring out only too clearly how much we are behind in our conception of what is right and proper in education. At this stage-the commencement of original investigation-says Prof. Nichols, there is a critical point. Further success depends upon several matters which have been necessarily somewhat neglected during the earlier periods. In the first place, the student must acquire independence and self-reliance ; he himself must face the experimental difficulties of the problem upon which he may be engaged, and must overcome them by devices of his own. Surely, we ought not to wait so long - the first essential in teaching scientific method should be to develop habits of independence ; and if from the outset we lead students, as far as possible, always to take up the attitude of the discoverer, there should be no critical point in their career, but they should insensibly escape from leading-strings and walk alone.

Being prepared specially for students at Cornell University, the book will scarcely be used very widely, and, indeed, is not suited for general use, I imagine; yet it appears to me to be of considerable interest to teachers, as marking a distinct step forward in the evolution of the text-book of the future. There can be little doubt that those students, at all events, who have a technical career in prospect, will be taught on lines such as are indicated by the arrangement of the subject-matter adopted by Prof. Nichols - that after going through a qualifying introductory course, in which they gain a general understanding of the main principles and of method, they will devote their attention to the technical study of whatever branch they may select. But it is to be hoped that they will be so taught at school that the introductory college course will not only be much shorter than is at present necessary, but of a much higher character; and that, as I have said above, they will be inquirers from the outset.

To carry such a scheme as I contemplate in this article into execution, however, teachers of all subjects must be trained in the school of research: surely this is the keynote of future progress in education, indeed of our national progress. 